\title{
Teaching Petrarchan and Anti-Petrarchan Discourses in Early Modern English Lyrics
}

\author{
Purificación Ribes \\ University of Valencia, Facultad de Filología, Traducción y Comunicación \\ Dpto. Filología Inglesa y Alemana \\ Avda. Blasco Ibáñez, 32, 46010 Valencia, Spain \\ Tel: 34-963-983-004 E-mail: purificacion.ribes@uv.es
}

Received: December 21, 2011

doi:10.5430/ijhe.v1n1p62
Accepted: January 9, 2012

Published: May 15, 2012

URL: http://dx.doi.org/10.5430/ijhe.v1n1p62

\begin{abstract}
The aim of the present article is to help students realize that Petrarchism has been an influential source of inspiration for Early Modern English lyrics. Its topics and conventions have lent themselves to a wide variety of appropriations which the present selection of texts for analysis tries to illustrate. A few telling examples from Spenser, Sidney, Donne and Marvell have been chosen where the topic of the lady cast as a valuable treasure is variously addressed. Whereas Spenser's Sonnet 15 of his Amoretti conveys the lover's confident hope of its possession in a near marriage, Sidney's Sonnet 37 of Astrophil and Stella portrays his frustration at the idea of being robbed of his cherished jewel by a less worthy rival. Donne's The Sun Rising extends the image of the valuable treasure to include the lyric I, while removing the traditional Petrarchan opposition between charitas and eros, whereas Marvell's To his Coy Mistress inscribes his parody of the Petrarchan topic of the lady as unattainable jewel within the carpe diem tradition.
\end{abstract}

Keywords: Teaching, Petrarchism, Anti-Petrarchism, Early Modern, English Lyrics

\section{Introduction}

One of the goals of literary studies is to make students aware of the close connection between literature and society (Note 1). A proper appraisal of this interdependence, moreover, can only be achieved if the student realizes the transformations that certain literary conventions have undergone in the course of time. Chief among these is Petrarchism, a fruitful tradition that has given rise to a wide variety of post-Petrarchan discourses, which range from close imitations of its topics and devices to open rejections of them (Note 2). As is often the case, the most complex and suggestive experiments lie between both extremes, and their outcome not only partakes of Petrarchan conventions but also includes a number of innovations which are often interspersed with irony and humour.

Aware of the wide variety of post-Petrarchan discourses, a number of texts with a common topic - that of the lady cast as a valuable treasure - have been selected for analysis. In each case, the students' attention is drawn to the specific devices which help articulate the different appropriations of the topic (Note 3) since, whereas Spenser's Sonnet 15 of his Amoretti conveys the lover's confident hope of its possession in a near marriage, Sidney's Sonnet 37 of Astrophil and Stella portrays his frustration at the idea of being robbed of his cherished jewel by a less worthy rival. Similarly, Donne's The Sun Rising extends the image of the valuable treasure to include the lyric I, while removing the traditional Petrarchan opposition between charitas and eros (Note 4), whereas Marvell's To his Coy Mistress inscribes his parody of the Petrarchan topic of the lady as unattainable jewel within the carpe diem tradition.

The commentaries which follow each poem, moreover, are devised as a means to help the students realize the multifarious nature of the Petrarchan tradition, in the hope of "enhancing their imaginative skills", the most important of which is - to borrow Hirsch's words - "to comprehend complexity" (2000, p. 171).

\section{Teaching Petrarchan and Anti-Petrarchan Discourses: Methodological Considerations}

As John Peck and Martin Coyle convincingly argue in Practical Criticism. How to Write a Critical Appreciation, "if you want to discuss [...] the role the text plays within the society of its day, the ways in which the poet, without realizing it, can internalize conservative values which at an explicit level he or she rejects, and what is said and what is left unsaid in 
a text $[\ldots]$ you have got to be able to show how big ideas are reflected even in the smallest details of a text" $(1995$, p. 120) (Note 5).

This sound principle is fully shared by Elaine Showalter when she describes what she considers the most useful method to approach literary texts. In her influential Teaching Literature, she insists that "the fundamental critical technique we expect literature students to learn is close reading [...] Before or along with attention to factors outside the text, students have to understand something about the verbal, formal and structural elements of the words themselves (2003, p. 56), an idea similarly emphasized by Malcolm Hebron in his lucid Mastering the Language of Literature, where he argues that "the close study of sound, grammar and lexis is a valuable approach to critical appreciation in its own right" (2004, p. 171).

As the following pages show, we are persuaded that this method is particularly useful to teach students the art of critical thinking, an art that, in Biddy Martin's words, can be achieved by "showing students to keep questions open and convince them that meaning, agency and value are not in one place" (1997, p. 12).

This type of approach is especially productive when analysing the rich and multifarious hypertextual transformations of the numerous hypotexts that re-create Petrarchan issues and devices. It is by approaching texts in this light that students can develop that "understanding of otherness" that Burwitz-Melzer claims as an essential feature of literary studies" (2001, p. 29).

\section{Spenser's Spiritual Treasure vs. Sidney's Lost Jewel}

\subsection{Spenser's Amoretti 15}

Although certain critics such as Greene extend the limits of Post-Petrarchism to contemporary lyrics (Note 6), most authors agree that Petrarchism enjoyed its greatest popularity in England during the last decades of the sixteenth century, particularly in the sonnet sequences of Sidney and Spenser. In spite of the marked differences of approach between Sidney's Astrophil and Stella and Spenser's Amoretti, students can easily realize the significant number of topics, attitudes and rhetorical devices that both collections share.

Taking into account that Sidney is the more innovative of the two poets, it is pedagogically advisable to offer the students a first contact with Petrarchism through one of Spenser's sonnets, in spite of which they must be made aware that Spenser's Amoretti significantly depart from their Petrarchan source in a number of ways, particularly in the lack of tension which the happy ending of the sequence entails. Unlike Wyatt's "hind", who cannot be hunted by the lyric I because she already belongs to "Caesar",

Who list her hunt, I put him out of doubt,

As well as I, may spend his time in vain.

And graven with diamonds in letters plain

There is written, her fair neck round about:

Noli me tangere, for Caesar's I am,

And wild for to hold, though I seem tame (11.9-14) (Note 7).

the hind in Spenser's Amoretti is willing to be "hunted"

So after long pursuit and vaine assay,

When I all weary had the chace forsooke,

The gentle deare returnd the selfe-same way,

Thinking to quench her thirst at the next brooke.

There she beholding me with mylder looke,

Sought not to fly, but fearelesse still did bide:

Till I in hand her yet halfe trembling tooke,

And with her owne goodwill hir fyrmely tyde (11. 5-12) (Note 8).

Whereas Anne Boleyn cannot free herself from the king, Elizabeth Boyle is free to marry her suitor. Sonnet 67 symbolizes their betrothal and, conventional though the tone of the sequence is (Note 9), students should be made aware that the hunting metaphor systematically illustrates the lover's frustration. This is probably the only case within the 
Petrarchan tradition when a deer willingly surrenders to the advances of his hunter. Students should be reminded that it is against this background that Spenser's Sonnet 15 can only be read.

Sonnet 15

Ye tradefull Merchants, that with weary toyle,

do seeke most pretious things to make your gain;

And both the Indias of their treasures spoile,

what needeth you to seeke so farre in vaine?

For loe my love doth in her selfe containe

all this worlds riches that may farre be found,

if Saphyres, loe her eies be Saphyres plaine,

if Rubies, loe hir lips be Rubies sound:

if Pearles, hir teeth be pearles both pure and round;

if Yvorie, her forhead yvory weene;

if Gold, her locks are finest gold on ground;

if silver, her faire hands are silver sheene.

But that which fairest is, but few behold,

her mind adornd with vertues manifold. (Note 10)

Sonnet 15 of the Amoretti displays a number of Petrarchan features, starting with its rhyme scheme, which is known as Spenserian Sonnet. It consists of three quatrains and a couplet rhyming abab, bcbc, cdcd, ee. The compactness of the rhyme scheme corresponds to the semantic connection between the three quatrains, as they all deal with the idea of a fabulous treasure that can be perceived by the senses. The final couplet introduces a new rhyme (ee) and also the idea that the lady embodies an even more valuable treasure than the one already described, although its spiritual nature prevents ordinary lovers from seeing it.

In the first quatrain the lyric I addresses hypothetical merchants who trade with precious goods from distant lands. He stresses their hard work which often involves unlawful practices, such as spoil. He ends the first quatrain with a rhetorical question that stresses the uselessness of the merchants' "weary toyle", since the most valuable treasures of both th'Indias are closer to them that they had ever imagined.

In the second quatrain the lyric I provides evidence that the most fabulous treasure in the world is near them and unravels its nature: it is his beloved that contains "all this worlds riches that may farre be found" (1.6). He devotes the remaining two lines of the second quatrain as well as the four lines of the third quatrain to name those parts of her beloved whose physical appearance resemble different gems and precious metals.

Spenser resorts to the employment of diverse rhetorical devices in order to persuade his addressee of the high value of the lady. He uses isocolon for a cumulative effect, which is reinforced by the anaphoric repetition of the conditional conjunction "if" at the beginning of the successive lines:

if Saphyres, loe her eies be Saphyres plaine,

if Rubies, loe hir lips be Rubies sound:

if Pearles, hir teeth be pearles both pure and round;

if Yvorie, her forhead yvory weene;

if Gold, her locks are finest gold on ground;

if silver, her faire hands are silver sheene. (11.7-12)

In order to make his statement more forceful, he replaces the customary simile with an invitation to state that his lady does not simply resemble a valuable treasure but is herself a jewel. Thus, instead of saying: "my lady's eyes are like sapphires", he says: "look, the eyes of my beloved are sapphires". He transforms his lady's eyes, lips, teeth, forehead, locks and hands into sapphires, rubies, pearls, ivory, gold and silver, respectively.

In order to enhance even more the uniqueness of her lady's physical beauty, he consistently places a positive adjective after each of the gems and metals into which she has been transformed, and whose rare beauty nobody questions: Thus, 
her eyes are not just ordinary sapphires, but "Saphyres plaine"; her lips, "rubies sound"; her teeth, "pearles pure and round"; her forhead, "yvory weene"; her locks, "finest gold on ground"; her hands, "silver sheene". This rhetorical device makes his beloved "jewel" unique.

The adversative conjunction "but" at the beginning of line 13 partly modifies the reader's set of expectations by adding new information which completes the portrait of his lady. In line with the hyperbolical praise of the preceding lines, the lyric I highlights her virtuous nature. Aware that the sonnet is approaching its end, and that moral virtues do not easily lend themselves to visual description, he concludes his poem by inviting his readers to look at her with the eyes of their imagination. But, as the lyric I proclaims at the end of the poem, this view is not open to ordinary men, but is reserved to the select few who can "behold" the moral richness of his beloved:

\section{But that which fairest is, but few behold,}

her mind adornd with vertues manifold. (11.13-14)

The serene attitude of the poet and the absence of reproaches to his lady make full sense when analysed within the context of a sequence that ends in happy marriage. Even if the lady is not described as a passionate and responsive woman, but is likened to cold stone and metal, that is a high tribute to her chastity, which is only natural in a woman whose faithfulness should never be suspected by her future husband. Chaste women are valuable commodities in noble households. As Ben Jonson would highlight in To Penshurst, it is they who are ultimately responsible for the purity of their lineage:

These, Penshurst, are thy praise, and yet not all.

Thy Lady's noble, fruitful, chaste withal.

His children thy great Lord may call his own:

A fortune, in this age, but rarely known (11. 89-92) (Note 11)

\subsection{Sidney's Lost Jewel: Astrophil and Stella 37}

My mouth doth water, and my breast doth swell,

My tongue doth itch, my thoughts in labour be;

Listen then, lordings, with good ear to me,

For of my life a riddle I must tell.

Towards Aurora's court a nymph doth dwell,

Rich in all beauties which man's eye can see;

Beauties so far from reach of words, that we

Abase her praise, saying she doth excel;

Rich in the treasure of deserved renown;

Rich in the riches of a royal heart;

Rich in those gifts that give the eternal crown;

Who though most rich in these, and every part

Which make the patents of true worldly bliss,

Hath no misfortune, but that Rich she is. (Note 12)

Sidney's sequence is closer to the spirit of Petrarch's Canzoniere than Spenser's because of the constant struggle between the two types of love - charitas and eros - that it dramatizes (Note 13). Unlike the lyric I in Spenser's Amoretti, Astrophil's physical love for Stella cannot be fulfilled, probably because his beloved - like Petrarch's Laura- is already married (Note 14).

In Sonnet 37, Sidney builds a riddle with the polysemic term "rich", an attribute traditionally employed to praise the lady. As usually, the lyric I variously illustrates the "richness" of his beloved, only to puzzle the reader at the very end, when he says that she has "no misfortune but that Rich she is". The paradox wittily employed by Sidney makes full sense when one realizes that "Rich" is the lady's married name, and, to judge from the poet's words, that has made her most unfortunate. Not only has the poet lost his "treasure", but it has been misused by its new owner. 
Petrarchan ladies are often associated with valuable treasures. Their meaning, however, is far from fixed but changes according to the stance of the lyric I. Whereas Spenser in Sonnet 15 calmly praises its worth in the hope of possessing it in a near future, Sidney regrets the devaluation of his wished-for treasure, as his rich rival owns it. Sidney's sonnet, though more original and witty than Spenser's, nevertheless falls within the conventional group of poems that lament unrequited love. Later representatives of Post-Petrarchism — notably Donne and Marvell- offer the reader poems where mutual love (Note 15) —or the hope of reaching it — does not exclude irony and wit.

\section{Pre-Lapsarian Wealth in Donne's The Sun Rising}

\section{The Sun Rising}

Busy old fool, unruly Sun, Why dost thou thus,

Through windows, and through curtains call on us?

Must to thy motions lovers' seasons run?

Saucy pedantic wretch, go chide

Late school-boys, and sour prentices,

Go tell court-huntsmen that the King will ride,

Call country ants to harvest offices;

Love, all alike, no season knows, nor clime,

Nor hours, days, months, which are the rags of time.

Thy beams, so reverend and strong

Why shouldst thou think?

I could eclipse and cloud them with a wink,

But that I would not lose her sight so long:

If her eyes have not blinded thine,

Look, and tomorrow late, tell me

Whether both th'Indias of spice and mine

Be where thou left'st them, or lie here with me.

Ask for those Kings whom thou saw'st yesterday,

And thou shalt hear: "All here in one bed lay".

She is all States, and all Princes I,

Nothing else is:

Princes do but play us; compared to this,

All honour's mimic; all wealth alchemy.

Thou sun art half as happy as we,

In that the world's contracted thus;

Thine age asks ease, and since thy duties be

To warm the world, that's done in warming us.

Shine here to us, and thou art everywhere;

This bed thy centre is, these walls, thy sphere. (Note 16)

Like Spenser, Donne in The Sun Rising establishes a comparison between the richest treasures, which are usually associated with the Indias, and her lady, that surpasses them in value. Donne's "jewel", however, is not that chaste maid who will dwindle into a virtuous wife, but the woman lying in her lover's bed, as the lyric I, persuaded of the rich treasure that he already possesses, tells the sun: "Look, and tomorrow late, tell me / Whether both th'Indias of spice and mine/ Be where thou left'st them, or lie here with me" (11.16-18) (Note 17). 
If the lyric I in Spenser's sonnet 15 feels proud of belonging to the select few who can appreciate the unique virtues of his lady, the lover in The Sun Rising places himself at a level with his beloved. After telling the sun that the world's treasure lies with him in bed, he lets him know that it is the two of them that now rule the universe: "Ask for those Kings whom thou saw'st yesterday, / And thou shalt hear: "All here in one bed lay"' (11.19-20).

His witty employment of hyperbole is more daring than Spenser's, since his poem progressively unravels a scale of values that clashes with those of his society. Whereas Spenser found it natural that "tradeful Merchants" sought the most precious things that made their gain" (11.1-2), and then simply let them know that his lady was the most valuable jewel, Donne places his lovers in a new golden age where love "all alike, no season knows, nor clime, / Nor hours, days, months, which are the rags of time" (11.9-10).

The refined nature of the lovers enables them to devote all their time to the noble exercise of love, whereas the world surrounding them strenuously seeks riches and honours. The lover's self-assurance contrasts with the traditional bashfulness and insecurity of the Petrarchan lover, as can be stated at the very beginning of The Sun Rising, where he dares chide the Sun for waking him and his beloved.

In Donne's customary vein, the poem opens in a surprising way, by addressing the Sun as "busy, old fool". The initial position of the adjective "busy", which is further emphasized by means of metrical inversion (trochaic foot within a iambic line), anticipates the relevance of the opposition between the strenuous activity that moves the world in search of riches and honours, and the serene and joyous contemplation of the lovers, who are aware that they belong to a better world, that golden age where an eternal spring renders work unnecessary. That is why the lyric I asks the sun rhetorically: "Must to thy motions lovers' seasons run?" (1.4).

The poem ends in a humorous vein, by letting the "old" sun know that he is about to feel great relief, since he no longer has to warm the rest of the world, but merely them, who are the true universe: "Thine age asks ease, and, since thy duties be / To warm the world, that's done in warming us" (11.27-28). As the sun knows, the lyric I and his beloved are "all States" and "Princes" (1.21), to the extent that worldly Princes "do but play" them, and worldly riches are but dross (1.23) (Note 18). It is the alchemical power of love that renders lovers genuine, and worldly values, fake (Note 19).

\section{Post-Lapsarian Dearth in Marvell's To his Coy Mistress}

\section{To his Coy Mistress}

Had we but world enough, and time,

This coyness lady were no crime.

We would sit down, and think which way

To walk, and pass our long love's day.

Thou by the Indian Ganges' side

Shouldst rubies find: I by the tide

Of Humber would complain. I would

Love you ten years before the Flood:

And you should if you please refuse

Till the Conversion of the Jews.

My vegetable love should grow

Vaster than Empires, and more slow.

An hundred years should go to praise

Thine eyes, and on thy forehead gaze.

Two hundred to adore each breast;

But thirty thousand to the rest.

An age at least to every part,

And the last age should show your heart.

For Lady you deserve this state;

Nor would I love at lower rate. 
But at my back I always hear

Time's wingèd chariot hurrying near:

And yonder all before us lie

Deserts of vast eternity.

Thy beauty shall no more be found,

Nor, in thy marble vault, shall sound

My echoing song: then worms shall try

That long preserved virginity:

And your quaint honour turn to dust;

And into ashes all my lust.

The grave's a fine and private place,

But none I think do there embrace.

Now therefore, while the youthful hue

Sits on thy skin like morning dew,

And while thy willing soul transpires

At every pore with instant fires,

Now let us sport us while we may;

And now, like amorous birds of prey,

Rather at once our time devour,

Than languish in his slow-chapped power.

Let us roll all our strength, and all

Our sweetness, up into one ball:

And tear our pleasures with rough strife,

Thorough the Iron gates of life.

Thus, though we cannot make our sun

Stand still, yet we will make him run. (Note 20)

Strong awareness of the passage of time and the urgent need to find a way of stopping its tragical consequences is the ultimate message of Marvell's To his Coy Mistress. Unlike Donne's The Sun Rising, the lyric I suffers because his love is unrequited and, following the carpe diem tradition, he tries to persuade his lady that her coyness is a crime.

The poem is structured in three sections which correspond to the three parts of a syllogism. In the first section the lyric I tells his lady that he would behave like a Petrarchan lover and adore her for ever if they were immortal and had "world enough and time" (1.1). In the second section he reveals that mortality is the obstacle that hinders that behaviour, since he permanently states that "Time's winged chariot is hurrying near" (1. 22). In the third part he offers the traditional conclusion to the syllogism by telling his beloved that they must take advantage of time while they are still young because the sun cannot be made to "stand still" (11. 45-46).

Whereas in The Sun Rising the happy lovers wished to stop the passage of time, the lyric I of To his Coy Mistress convincingly argues against that fallacy. So far, the lady has been unresponsive to his requests, and he resorts to irony as the best means of persuading her of the unattractiveness of the Petrarchan ideal, which she seems to fancy. By means of hyperbole and irony, Marvell ridicules the unfailing constancy of the Petrarchan lover and the repeated rejection of his beloved. Marvell extends the situation beyond the span of a lifetime into eternity, thereby showing its absurdity:

$$
\text { (...) I would }
$$

Love you ten years before the Flood:

And you should if you please refuse

Till the Conversion of the Jews. (11.7-10) 
His portrayal of the Petrarchan tradition includes the customary association of the lady with the precious jewels from the East:

Thou by the Indian Ganges' side

Shouldst rubies find (11. 5-6)

as well as the lover's detailed praise of his lady:

And hundred years should go to praise

Thine eyes, and on thy forehead gaze.

Two hundred to adore each breast;

But thirty thousand to the rest.

An age at least to every part,

And the last age should show your heart. (11.13-18)

Finally, he also mocks the lover's exaggerated patience:

My vegetable love should grow

Vaster than Empires, and more slow. (11.11-12)

Against this artificial and lifeless portrait, he sets the vivid description of the passage of time, which reduces everything to ashes:

Thy beauty shall no more be found,

Nor, in thy marble vault, shall sound

My echoing song: then worms shall try

That long preserved virginity:

And your quaint honour turn to dust;

And into ashes all my lust. (11.25-30)

He then contrasts these images of death with the lady's youthful beauty and passionate desire:

Now therefore, while the youthful hue

Sits on thy skin like morning dew,

And while thy willing soul transpires

At every pore with instant fires. (11.33-36)

and offers her the possibility of triumphing over "the slow-chapped power" of Time by devouring it "like amorous birds of prey" (1l.38-40), so that, as he tells his lady, "though we cannot make our sun /Stand still, yet we will make him run" (11. 45-46).

The Metaphysical witty variations on the Petrarchan tradition are clear instances of that "continuing struggle between difference and sameness" which Dubrow sees at the core of Petrarchism and which, in his view, is best symbolized by the oxymoron, "its signature trope" (1995, p. 254).

\section{Conclusion}

As the examples from the preceding pages have variously illustrated, different texts of the Petrarchan tradition, "put their speaker in relation to another character cast in the role of object, and largely invent their politics, society, and world from the exchanges of these two" (Greene 1991, p. 14). Aware of the wide variety of texts available for study, we have offered the student a few significant examples that cast that object as a valuable treasure, and have prompted him/her to look at the various strategies of elaboration by means of which these poems have advanced plots, established characters, arranged space and, above all, created worlds.

\section{References}

Bennett, A. \& Royle, N. (1999). Introduction to Literature, Criticism and Theory. Harlow: Pearson.

Burwitz-Melzer, E. (2001). Teaching Intercultural Communicative Competence through Literature. In M.N. Byram, A. Nichols \& D. Stevens (Eds.). Developing Intercultural Competence in Practice. New York: Multilingual Matters. 
Byram, M., Nichols, A. \& Stevens, D. (Eds.) (2001). Developing Intercultural Competence in Practice. New York: Multilingual Matters.

Cheney, P. \& A. Lake Prescott, A. (Eds.). (2000). Approaches to Teaching Shorter Elizabethan Lyrics. New York: Modern Language Association.

Cummings, R., (Ed.) (2000). Seventeenth-Century Poetry. An Annotated Anthology . Oxford: Blackwell.

Donne, J. Songs and Sonnets / Canciones y Sonetos. Bilingual edition. Ribes, P. (Ed. and Trans.) (1996). Madrid: Cátedra.

Dubrow, H. (1995). Echoes of Desire. English Petrarchism and its Counterdiscourses. Ithaca: Cornell University Press.

Durant, A. \& Fabb, N. (1992). Literary Studies in Action. London: Routledge.

Greenblatt, S. (Gral. Ed.) (2006). The Norton Anthology of English Literature. (8th ed.) New York: W.W. Norton.

Greene, R. (1991). Post-Petrarchism. Origins and Innovations of the Western Lyric Sequence. Princeton: Princeton University Press.

Gross Davis, B. (2009). Tools for Teaching. (2nd ed.) San Francisco: Jossey-Bass Higher and Adult Education Series.

Hebron, M. (2004). Mastering the Language of Literature. Houndmills: Palgrave.

Hirsch, J. (2000). Provoking Thought: Teaching Romeo and Juliet through Dramatic Technique. In M. Hunt (Ed.). Approaches to Teaching Shakespeare's Romeo and Juliet (pp. 163-172). New York: Modern Language Association.

Hunt, M. (Ed.). (2000). Approaches to Teaching Shakespeare's Romeo and Juliet. New York: Modern Language Association.

Kennedy, W. J. (2000). Framing the Authentic Petrarch: From the Rime Sparse to Astrophil and Stella. In P. Cheney \& A. Lake Prescott (Eds.). Approaches to Teaching Shorter Elizabethan Lyrics (pp. 81-85). New York: Modern Language Association.

Kermode, F. \& Hollander, J. (Eds.) (1973). The Oxford Anthology of English Literature, Vol 1. Oxford: Oxford University Press.

Kerrigan, W. (1987). What was Donne Doing? South Central Review 4:2, 2-15. http://dx.doi.org/10.2307/3189160

Martin, B. (1997, January). Teaching Literature, Changing Cultures. Publications of the Modern Language Association of America, 7-25.

Peck, J. \& Coyle, M. (1995). Practical Criticism. How to Write a Critical Appreciation. Houndmills: Palgrave.

Praz, M. (1958). The Flaming Heart. Essays on Crashaw, Machiavelli and Other Studies of the Relations between Italian and English Literature from Chaucer to T.S. Eliot. New York: Doubleday Anchor Books.

Ruffo-Fiore, S. (1972). The Unwanted heart in Petrarch and Donne. Comparative Literature 24, 319-327. http://dx.doi.org/10.2307/1769459

Showalter, E. (2003). Teaching Literature. Oxford: Blackwell.

Sidney, P. Duncan-Jones, K. (Ed.) (1984). Selected Poems. Oxford: Clarendon Press. 


\section{Notes}

Note 1. We fully share Alan Durant and Nigel Fabb's view that one of the main aims of literary studies is "to offer insight into past and present cultures and society and develop the student's cultural thinking" (1992, p. 5).

Note 2. William Kennedy aptly points to the "simultaneous strangeness and immediacy of Petrarch's verse for Elizabethan culture" (2000, p. 85).

Note 3. Our approach to teaching the different appropriations of the Petrarchan tradition is in line with Barbara Gross Davis' views, as expressed in Tools for Teaching. She claims that "students learn best when they take an active role [...] and apply concepts and ideas" (2009, p. 168).

Note 4. As Silvia Ruffo-Fiore points out regarding John Donne, “his greatness as innovator appears in his 'imitation' of Petrarch, in his discovery of latent and undeveloped possibilities of treating love within the Petrarchan mode itself" (1972, p. 319).

Note 5. Andrew Bennett and Nicholas Royle express a similar view on the need to analyze the verbal texture of literary texts in relation to their specific circumstances of production and reception (1999).

Note 6. According to him, "Petrarch's disparate models [...] were transformed by his infusion of several elements and passed on, a new whole, to European and New World poets of five ensuing centuries" (Greene 1991, p. 22).

Note 7. From ms. 1913. Repr. in Kermode (1973, p. 621).

Note 8. From Sonnet 67. Repr. Greenblatt (2006, p. 437).

Note 9. In Praz's opinion, “the psychological subtlety of Petrarch is absent from Spenser” (1958, p. 278).

Note 10. Repr. Kermode (1973, p. 821).

Note 11. Repr. Cummings (2000, p. 87)

Note 12. Repr. Sidney, edited by Duncan-Jones (1984, p. 135)

Note 13. The final words of the lyric I in Sonnet 71"But ah, Desire still cries, 'give me some food" are a telling example of he lover's conflict between charitas and eros.

Note 14. As Kennedy points out, "Laura was, despite the impression that Petrarch gives of her virginal aloofness, a married woman with eleven children" (2000, p. 86).

Note 15. William Kerrigan, among others, observes that Donne "celebrates an ideal of mutual love that is foreign to Petrarchism" (1987, pp. 11-12).

Note 16. Repr. Donne, edited by Ribes (1996, pp. 210-212).

Note 17. These lines evidence the soundness of Dubrow's view that "Donne neither embraces Petrarchism enthusiastically, as some revisionist readers assert, nor rejects it under the guise of participating in it, as others claim [...] Rather Donne establishes himself both inside and outside Petrarchism” (1995, p. 205).

Note 18. This poems exemplifies Dubrow's view that" "Donne pushes the conceits of Petrarchism to an extreme, often taking them literally" (1995, p. 222).

Note 19. Mario Praz's remarks on the structure of Donne's lyrics perfectly applies to The Sun Rising, where the reader gains progressive insight into his original understanding of wealth and honour as they are explored throughout the poem. He says: "The unit is not the line, as in many sonneteers, and not even the stanza, but the entire poem in its serpentine swerving from one excitement to another" (1958, p. 190).

Note 20. Repr. Cummings (2000, pp. 401-402). 